- determine the type of source of UV radiation that will provide uninterrupted emission of radiation under conditions of vibration, different acceleration and impact;

- optimize the placement of the UV radiation source to reduce the size and number of «dead zones» in which the radiation does not fall, and determine the radiation power that will ensure the energy-efficient disintegration of toxicants, depending on their composition and content in air mixtures.

\title{
References:
}

1. Halak, O. V., Sakhnenko, M. D., Karakurkchi, H. V., Matykin, O. V., Belousov, I. O., \& Kosarev, O. V. (2018). Metody ochyshhennya gazovyx vykydiv vid nebezpechnyx ximichnyx rechovyn dlya pidvyshhennya efektyvnosti filtruvalnyx system [Methods for purification of gas emissions from hazardous chemicals to improve the efficiency of filtration systems]. Visnyk Natsionalnoho Tekhnichnoho Universytetu «KhPI», 18(1294), 89-93.

2. Parmon, V. N. (1991) Fotokataliz: Voprosy terminologii [Photocatalysis: Terminology Issues]. Fotokataliticheskoe preobrazovanie solnechnoy energii.

3. Zaynishev, A. V., \& Polunin, G. A. (2012). Primenenie ul'trafioletovykh svetodiodov v fotokataliticheskikh vozdukhoochistitelyakh dlya ochistki vozdukha kabin mobil'nykh mashin [The use of ultraviolet LEDs in photocatalytic air purifiers for air purification of cabins of mobile cars]. Tehnologii tehnosfernoy bezopasnosti, 6(46), 1-10.

4. Zaynishev, A. V., \& Polunin, G. A. (2014) Osobennosti vozdushnogo potoka v spiral'nom fotokataliticheskom vozduhoochistitele [Features of the air flow in a spiral photocatalytic air purifier]. Materialyi LIII Mezhdunarodnoy nauchno-tehnicheskoy konferentsii «Dostizheniya nauki - agropromyishlennomu proizvodstvu», 4, 121-125.

5. Sakhnenko N., Ved M., Karakurkchi A. \& Galak A. (2016) Study of synthesis and properties of manganese-containing oxide coatings on alloy VT1-0. Eastern-European Journal of Enterprise Technologies, 3, 5(81), 37-43.

6. Halak, O. V., Karakurkchi, H. V., \& Hrybyniuk, Ya. V. (2016). Filtroventylyatsiyni ustanovky (ahrehaty) statsio-narni ta na broneobyektakh [Ventilation installations (units) are stationary and on armored objects]. Systemy ozbroiennia i viiskovoi tekhniky, 4(48), 5-9.

\section{APPROACH TO CHOOSING A DRIVING ROUTE WHEN ORGANIZING A CAR DRIVING PRACTICE}

\section{Ruslan Kuzmenko ${ }^{1}$}

DOI: https://doi.org/10.30525/978-9934-588-11-2_10

While organizing the process of learning practical driving, a considerable role is played by the choice of the venue, namely the choice of playground or a fully-fledged route in the city. Typically, in primary classes, such training takes place at separate sites of specialized racetracks. As the practical skills are consolidated, the combination of skillful application of theoretical knowledge of learning becomes a

\footnotetext{
${ }^{1}$ Hetman Petro Sahaidachnyi National Army Academy, Ukraine
} 
more complex plane of practical driving, namely learning to drive a car on the roads under different road conditions.

Given the above, it can be noted that practical driving training can take place on several routes that differ from each other by a number of criteria. The consideration of these criteria when choosing a training route is an important practical task that determines the importance of this topic.

The generally accepted approach to choosing a training route is based on the classical mathematical problem of determining a circular route that passes through several points, provided that each point is passed through only once and the end point coincides with the initial one $[2$, p. $127 ; 3$, p. 63]. A more complex principle of the multicriteria approach was considered in papers $[4$, p. $74 ; 5$, p. 68]. In view of the above, it is proposed to consider the choice of a training route in terms of logistics, taking into account the qualitative and quantitative indicators $[7 ; 8]$.

In order to solve the problem of choosing a training route, 12 criteria have been developed that satisfy the requirements of the system characterizing road safety «Driver-Car-Road-Environment» [3, p. 56].

There are criteria that characterize the learner-driver:

- the qualification of the learner-driver(level of theoretical knowledge and practical skills);

- psychological and emotional state of the learner-driver, depending on the traffic conditions in the traffic flow.

The criteria that characterize the training car include:

- correspondence of the technical characteristics of the educational vehicle (overall dimensions);

- compliance of the technical condition with the requirements of the legislation;

- actual movement speed.

The criteria characterizing road conditions include:

- visibility in the direction;

- type and condition of the road surface;

- availability of means of traffic organization and their condition (road signs and marking);

- total length of ascents and descents with a slope of more than $40 \%$.

The criteria that characterize the environment include:

- natural and climatic conditions (time of year, weather conditions);

- complexity of route configurations (organization of crossroads, pedestrian crossings, public transport stops, etc.);

- traffic flow intensity.

Using the expert evaluation method, 20 experts determined the rank of each of the criteria. Due to this the most significant criterion is the highest value of rank.

The rank estimates obtained from all the questionnaires were entered into a spreadsheet to further determine the consistency of the Kendel coefficient and Pearson's criterion, and the values of the weights of each criterion were calculated. Average rank sums for all criteria, deviations and squared deviations of rank sums for 
each criterion were calculated relative to the average rank sums for all criteria for each expert group.

According to the obtained rank estimates of the criteria, the values of Kendel's coefficient of concordance $\mathrm{W}=0.61>0.6$ and Pearson's criterion $\mathrm{x}^{\wedge} 2=198.7>22.4$ are obtained, which satisfies the conditions of agreement of experts' opinions. Of all the weights determined, $y_{i}$ there were distinguished by all criteria the most significant ones that satisfy the condition $y_{i}>1 / \mathrm{n}$, where $\mathrm{n}=12$ is the number of evaluation criteria.

The results of calculations of the values of the weight coefficients of each criterion $y_{i}$ are presented in Figure 1.

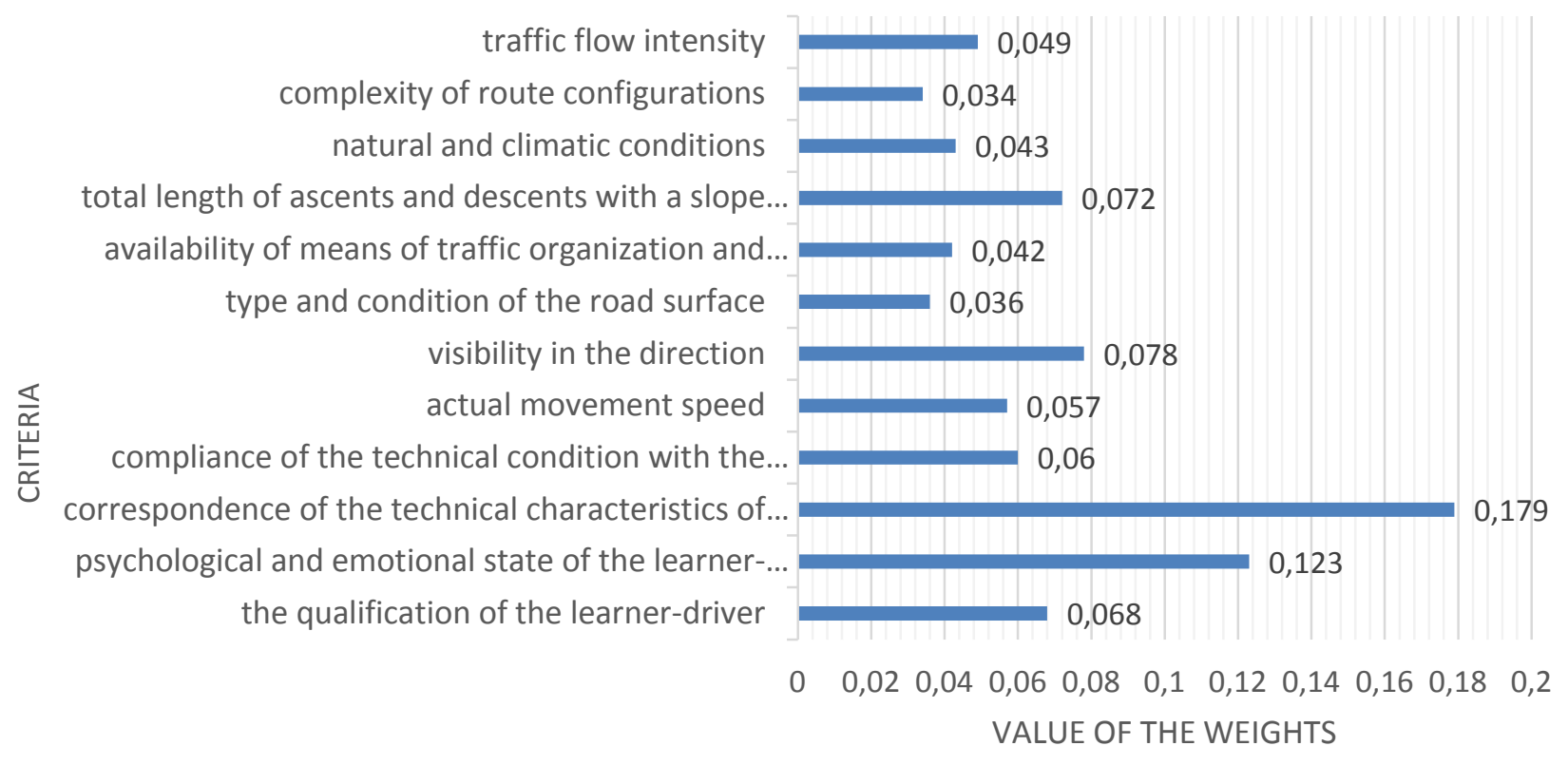

\section{Figure 1. Diagram of the values of the coefficients of the weights of the criteria that influence the choice of study route}

To determine all possible alternatives to the educational route of traffic and to evaluate them, it is necessary to calculate the final integral indicator. The calculations are performed on the basis of the methodology specified in [4, p. 124]. By this method, all the criteria are divided into three groups: quantitative, qualitative and relational, which increase the objectivity of the selection process. Qualitative indicators are obtained on the basis of statistical, reporting and reference data and are evaluated on a three-point scale: 1 - excellent, 2 - good, 3 - satisfactory.

The desirability function [4, p. 130] is used to reduce qualitative indicators to quantitative expression. To evaluate alternatives of routes by quantitative and qualitative indicators [4, p. 135], for each criterion a reference value is selected maximum or minimum, depending on its influence on the overall assessment, and its relative value is calculated.

The total integral index $K_{0}$ is calculated by the expression: 


$$
K_{0}=\sum_{i=1}^{n} K_{i} y_{i 0} \rightarrow \max
$$

where $K_{0}$ is the arithmetic mean score in the i-go criterion provided by the experts; $y_{i 0}$ is the weighting factor of the $\mathrm{i}$-th criterion.

The steps of choosing a training route are shown in Figure 2 where the final training route is chosen by the largest values of the integral indicators.

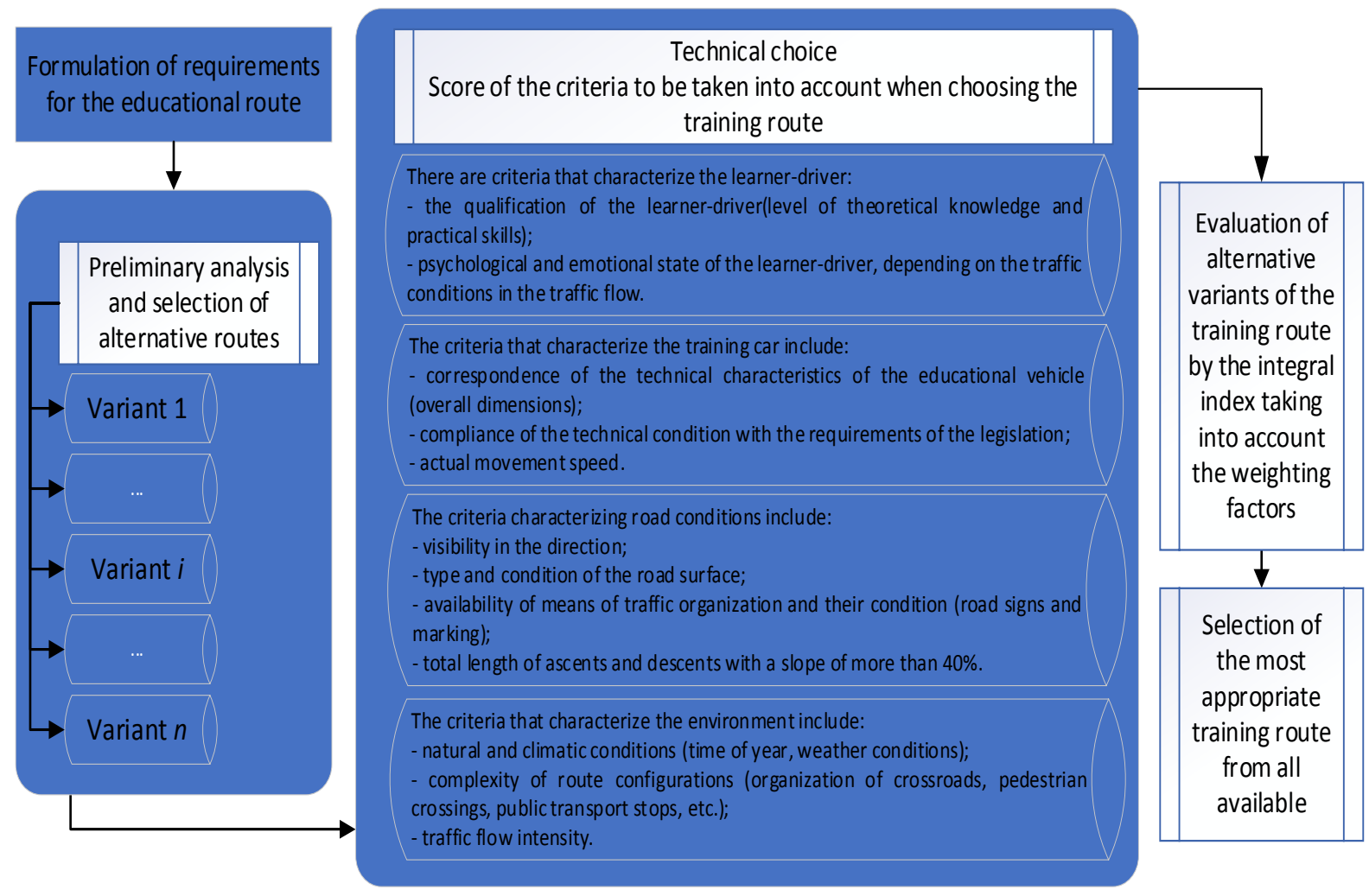

\section{Figure 2. Structural-logical scheme of choosing the educational route of movement}

In this paper, there has been developed a scheme that allows to choose from several alternatives the optimal educational route of movement. It should be noted that this approach takes into account the criteria stipulated by the Driver-Car-RoadEnvironment system.

\section{References:}

1. Sokur, I. V., Sokur, L. P., \& Gerasymchuk, W. W. (2009). Transport Logistics: Educ. manual. Kyiv: Center for Educational Literature. (in Ukrainian)

2. Bosnyak, M. G. (2010). Freight car transportations. Tutorial for students of specialty 7.100403 «Organization of transportation and management in transport (automobile)». Kyiv: Publishing House «Slovo». (in Ukrainian).

3. Gerzel, V. M., Marchuk, M. M., Fabritsky, M. A., \& Rizhy, O. P. (2006). Road transport, road conditions and traffic safety. Educ. Manual. Rivne: NSUPP. (in Ukrainian). 
4. Lukinsky, V. S., Berezhnoy, V. I., \& Berezhnaya, E. I. (2009). Logistics in examples and tasks: Educ. Manual. Moscow: Finance and Statistics. (in Russian)

5. Kurganov, V. M. (2003). Logistic traffic flows. Educ. Manual. Moscow: Publishing and trading corporation «Dashkov and KO». (in Russian)

6. Transport Logistics. Shared solutions to common challenges. Retrieved from:: https://www.itf-oecd.org/sites/default/files/docs/02logisticse.pdf (accessed 25 august 2019).

7. Albino, Vito \& Petruzzelli, Antonio \& Okogbaa, O. G. (2009). Managing Logistics Flows Through Enterprise Input-Output Models. 2008 IEEE International Conference on Industrial Engineering and Engineering Management, IEEM 2008. pp. 852-856. 10.1109/IEEM.2008.4737990.

8. Hesse, Markus \& Rodrigue, Jean-Paul. (2004). The transport geography of logistics and freight distribution. Journal of Transport Geography. 12. pp. 171-184. 10.1016/j.jtrangeo.2003.12.004.

\section{CHOOSING THE SHAPE OF A SEASONAL HEAT ACCUMULATOR}

\section{Anna Moskvitina ${ }^{1}$}

DOI: https://doi.org/10.30525/978-9934-588-11-2_11

The exhaustion of traditional fuel resources and environmental degradation adds relevance to research on renewable and alternative energy and the need to bring environmentally friendly energy sources to the energy balance of Ukraine. A promising direction is the use of heat of solar energy for communal heat supply, which can provide large heat needs even in temperate climates. Basically, methods for using the thermal energy of the sun as a whole are cost-effective, but the proportion of thermal solar energy is quite small. It is possible to significantly increase the efficiency of the use of solar energy in the presence of a seasonal heat accumulator of large thermal capacity. The problem of excess heat in the summer, when the demand for it is reduced, is relevant for existing heat-generating enterprises (CHP). It can also be solved by accumulating these surpluses with their further use in the heating period $[1$, p. $44 ; 2$, p. 58].

To reduce the unit cost of 1 GJ of stored heat, the efficient design of the heat accumulator should have minimal heat loss to the environment. When choosing the shape of the heat accumulator in the plan, you should try to simplify its shape as much as possible. Since the greatest heat loss occurs through the walls, it is desirable that their surface area is the smallest. It is well known that with the same volume, the ball has the smallest surface area. However, it is not rational to build a heat accumulator in the form of a ball in an effort to significantly reduce heat loss, since it is very difficult to calculate and constructively execute a spherical heat accumulator. For real construction, the configuration of a heat accumulator in the form of a cube is best suited, since the outer surface area is the smallest in it, so for further calculations

${ }^{1}$ Kiev National University of Construction and Architecture, Ukraine 